Journal of Telenursing (JOTING)

Volume 3, Nomor 1, Juni 2021

e-ISSN: 2684-8988

p-ISSN: 2684-8996

DOI: https://doi.org/10.31539/joting.v3i1.2075

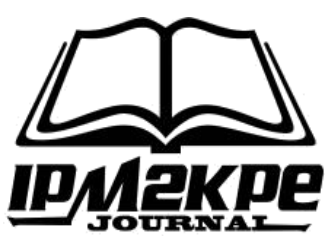

\title{
PENGALAMAN IBU USIA REMAJA MELAHIRKAN ANAK DI MASA PANDEMI COVID-19
}

\author{
Padila $^{1}$, Panzilion ${ }^{2}$, Juli Andri ${ }^{3}$, Nurhayati ${ }^{4}$, Harsismanto $\mathrm{J}^{5}$ \\ Universitas Muhammadiyah Bengkulu ${ }^{1,2,3,4,5}$ \\ padila@umb.ac.id ${ }^{1}$
}

\begin{abstract}
ABSTRAK
Penelitian ini bertujuan untuk mengeksplorasi pengalaman ibu usia remaja saat melahirkan anak di masa pandemi. Desain penelitian menggunakan jenis kualitatif dengan pendekatan fenomenologi. Dalam penelitian ini didapat tujuh partisipan ibu remaja yang berusia antara 19-21 tahun. Instrumen yang digunakan yaitu pedoman wawancara mendalam terkait pengalaman persalinan di masa pandemi COVID-19 ini. Uji keabsahan data menggunakan teknik desain triangulasi. Hasil penelitian menemukan 11 tema yaitu: usia dan pendidikan terakhir ibu, definisi persalinan, tahap persalinan, perasaan ibu ketika melahirkan, tindakan yang dilakukan ketika ibu usia remaja merasa cemas, perlakukan keluarga yang diberikan untuk perawatan bayi, pendapat tentang sikap yang diberikan keluarga kepada ibu, reaksi ibu dalam menghadapi perlakuan keluarga, pola yang ibu terapkan dalam proses menghadapi persalinan di masa pandemi COVID-19 dan dukungan yang diperoleh ibu muda dalam perawatan bayi ketika sakit. Simpulan, ibu usia remaja yang melahirkan selama pandemi COVID-19 menderita cemas tingkat sedang dan minimnya dukungan keluarga saat melahirkan serta menerima perlakuan dengan kualitas akses pelayanan kesehatan yang kurang.
\end{abstract}

Kata Kunci: Fenomenologi, Pandemi COVID-19, Pengalaman, Persalinan, Remaja

\begin{abstract}
This study aims to explore the experiences of adolescent mothers when giving birth to children during a pandemic. The research design used a qualitative type with a phenomenological approach. In this study, there were seven female adolescent participants aged 19-21 years. The instrument used was an in-depth interview guide related to the experience of childbirth during the COVID-19 pandemic. Test the validity of the data using the triangulation design technique. The results of the study found 11 themes, namely: the mother's last age and education, the definition of childbirth, the stage of childbirth, the mother's feelings during childbirth, the actions taken when the mother was anxious, treating the family for baby care, the opinion about the attitude that the family gave to the mother, the reaction of mothers in facing family treatment, patterns that mothers apply in the process of dealing with childbirth during the COVID19 pandemic and the support young mothers receive in caring for their babies when they are sick. In conclusion, teenage mothers who gave birth during the COVID-19 pandemic suffered from moderate anxiety and lack of family support during childbirth and received treatment with poor quality access to health services.
\end{abstract}

Keywords: Phenomenology, COVID-19 Pandemic, Experience, Childbirth, Adolescents 


\section{PENDAHULUAN}

Ketakutan di masa pandemi COVID-19 menghalangi para ibu untuk pergi ke rumah sakit. Jangankan untuk proses melahirkan, sekedar cek secara berkala perbulan saja membuat mereka menjadi stress, sehingga tidak sedikit ibu hamil memutuskan untuk melahirkan di rumah saja dengan bantuan tim medis dan alat kesehatan seadanya. Hal tersebut beresiko membahayakan kesehatan ibu dan bayi yang akan dilahirkan (Nosratabadi et al., 2020).

Hasil penelitian yang dilakukan Mollard \& Wittmaack (2021) mendapatkan hasil bahwa $61 \%$ wanita melaporkan dukungan yang tidak memadai untuk persalinan selama masa pandemi COVID-19 dan 20,5\% melaporkan bahwa mereka tidak merasa aman melahirkan di rumah sakit. Perempuan yang dites positif COVID-19 lebih cenderung berasal dari ras Asia, mereka melakukan persalinan secara caesar, ketika melahirkan tidak didampingi oleh pasangan dan menghentikan menyusui sebelum 6 minggu. Perubahan terkait pandemi pada praktik keperawatan maternitas mungkin terjadi dan mempengaruhi persepsi wanita melahirkan tentang keamanan dan dukungan di lingkungan rumah sakit dan gejala stres yang muncul selama masa pandemi COVID19.

Penelitian serupa juga dilaksanakan oleh Mortazavi (2020) yang melakukan studi fenomenologi deskriptif terhadap 19 wanita hamil, diantaranya ada yang mengalami gangguan ketenangan dan rutinitas kehidupan sehari-hari, tantangan baru yang disebabkan oleh pandemi, ketahanan dan kekuatan dalam menghadapi krisis dan adaptasi dengan kondisi baru, kondisi psikologis perempuan hamil semakin memburuk selama pandemi COVID-19. Sejauh ini penelitian yang ada hanya menelaah tentang pengalaman ibu yang melahirkan di masa pandemi COVID-19, namun belum ada spesifikasi yang mengkaji berdasarkan kategori usia. Oleh karena itu peneliti tertarik untuk melihat lebih sfesifik dari sisi usia remaja.

\section{METODE PENELITIAN}

Jenis penelitian yang digunakan oleh peneliti adalah penelitian kualitatif. Dengan menggunakan pendekatan fenomenologi deskriptif. Penggunaan metode ini diharapkan dapat mengupas pengalaman persalinan dan perawatan bayi baru lahir sehari-hari dalam mencegah penyebaran COVID-19 di rumah.

Rancangan ini dipilih karena peneliti menggali keluasaan, kekayaan dan kedalaman pengalaman seseorang. Teknik pengambilan sampel menggunakan metode accidental sampling, yaitu suatu teknik penetapan sampel yang secara langsung ditemukan dilapangan dianggap sampel tersebut dapat mewakili karakteristik.

Instrumen utama dalam penelitian ini adalah peneliti itu sendiri. Peneliti akan menggunakan alat bantu pengumpulan data untuk membantu penelitian yaitu dengan menjadikan diri peneliti sendiri sebagai instrumen penelitian yang dilengkapi dengan alat perekam wawancara yang menggunakan voice recorder dalam bentuk handphone.

\section{HASIL PENELITIAN}

\section{Karakteristik Partisipan}

Sebelum dilakukan penelitian, peneliti memberikan penjelasan pada ibu usia remaja dalam melahirkan anak di masa pandemi COVID-19 tentang tujuan, manfaat dan proses penelitian, kemudian memberikan lembar informed consent yang ditandatangani untuk menyatakan kesediaan menjadi partisipan dalam penelitian. Ibu Remaja yang 
bersedia menjadi partisipan dan memberikan persetujuan dalam lembar informed consent di wilayah kerja Puskesmas Telaga Dewa Kota Bengkulu.

\section{Analisis Tema}

Dalam penelitian kualitatif sebetulnya analisis data dilakukan pada saat pengumpulan data berlangsung dan setelah pengumpulan data. Saat peneliti melakukan wawancara, peneliti sudah melakukan analisis terhadap jawaban responden tersebut. Aktivitas analisis data Milles dan Huberman terdiri atas: data reduction, data display dan conclusion drawing/verification yang dilakukan secara interaktif dan berlangsung secara terus menerus sampai tuntas, sehingga datanya mencapai jenuh.

Berdasarkan metode Milles dan Huberman, diperoleh 11 tema yang menunjukkan pengalaman ibu usia remaja dalam melahirkan anak di masa pandemi COVID-19 yakni:

\section{Tema 1. Usia dan Pendidikan Terakhir Saat Ibu Melahirkan}

Usia dan pendidikan akhir saat melahirkan berdasarkan informasi dari partisipan yaitu:

"aku umur 19 dan Tamatan SMP” (P1)

"umur 20 dan tamat SMA" (P2)

"aku umur 21, SMA” (P3)

“umur 21, SD” (P4)

"aku kemaren umur 19 tahun, SMP" (P5)

"umur 20, SMP” (P6)

"umur 19, SD” (P7)

\section{Tema 2. Pengertian Persalinan}

Pengertian persalinan berdasarkan informasi dari partisipan yaitu:

"Proses ngeluarkan bayi" (P1)

"keluarnyo anak" (P2)

"keluarnyo anak lewat jalan lahir" (P3)

"melahirkan tu proses akhir dari kehamilan” (P4)

"lahirnya anak" (P5)

"waktunyo anak lahir" (P6)

"anak lahir lewat jalan lahir" (P7)

\section{Tema 3. Apakah Ibu Tahu Tahap Persalinan}

Tahapan persalinan berdasarkan informasi dari partisipan yaitu:

"tau aku, yang pertamo tu mules, bayi lahir dahtu motong ari-ari” (P1)

“iyo tau aku” (P2)

"kayak ibu-ibu yang lain tulah sakit perut, anak lahir, dahtu potong ari-ari” (P3)

"tau” (P4)

"kontraksi saket perot, anak lahir, kubur ari-ari" (P5)

"tau aku” (P6)

“tau, mules yang jelas, cak orang melahirkan biaso tulah” (P7)

Tema 4. Bagaimana Perasaan Ibu Melahirkan di Masa COVID-19 di Rumah Sakit

Perasaan ketika proses melahirkan berdasarkan informasi dari partisipan yaitu:

"takut nian aku dan bayi keno virus itu" mano mak aku dak biso ngawani pulo dibatasi kan (P1) 
"ouy stress nian aku takut ado apo-apo, mano ortu dak ngawani dak boleh dr pihak RS (P2)

"stress nian aku, baru pertamo kali soalnyo, covid pulo, ibu aku dak damping pulo” (P3)

"takut kek stress jelas, apolagi mak bak dak biso ke RS, kan hanya 1 yang pacak ngawani laki tulah” (P4)

"sebelum ngelahirkan tu lah cemas nian kareno rumah sakit ngebatasi kunjungan,umak aku dak ikut, gara-gara pandemi ko” (P5)

"takut aku dan bayi keno covid" (P6)

“iyo cemas nian, mano harus di rapid pulo blm lagi operasi SC”(P7)

\section{Tema 5. Berapa Lama Ibu Merasa Stress/Cemas yang Ibu Rasakan dan Kapan Perasaan Itu Berkurang}

Perasaan stress/cemas ketika proses melahirkan berdasarkan informasi dari partisipan yaitu:

"3 bulan sampe hari lahiran dan pas dah dibolehkan balek lega" (P1)

"3,5 bulan ado, dah nyampai rumah tenang" (P2)

"4 bulananlah, pas lah balek kerumah nengok mak cemee bekurang" (P3)

"3 bulan seingat aku polagi jelang lahiran, perasaan tu bekurang aku dan bayi sehat" (P4)

"3,5 bulanlah, stress bekurang pas dah mpai rumah" (P5)

"3 bulanan aku, cemee bekurang pas nengok anakku sehat" (P6)

"3 bulanan yang aku rasoi, stress bekurang pas dah dibolehkan balik" (P7)

\section{Tema 6. Apa yang Anda Lakukan Ketika Perasaan Cemas/Stress/Khawatir} Muncul yaitu:

Tindakan yang dilakukan ketika cemas berdasarkan informasi dari partisipan

"banyak-banyak do'a tulah aku” (P1)

"do'a minta biar idak cemas takut lagi" (P2)

"banyak-banyak nyebut tulah" (P3)

"tarik nafas pelan-pelan” (P4)

"kalau aku banyak-banyak doa" (P5)

"atur nafas" (P6)

"tarik nafas pelan-pelan" (P7)

\section{Tema 7. Bagaimana Perlakuan Keluarga Ketika Perawatan BBL di Rumah}

Perlakuan kelurga ketika perawatan BBL berdasarkan informasi dari partisipan yaitu:

"keluargo aku dukung, tapi banyak ngomel jugo" (P1)

"Alhamdulillah dibantu mak, meski cerewet" (P2)

"keluargo bantu kadang juga banyak diceramahin” (P3)

"banyak ngasih nasehat tapi nolong kurang" (P4)

"keluargo kadang-kadang ajo bantu, soalnyo mak tani pulo" (P5)

"banyaklah ngomel keluargo ni," (P6)

“setelah lahiran 2-3 kali mak datang, kalo yang lain dak do" (P7) 
Tema 8. Menurut Anda Mengapa Keluarga Bersikap dan Melakukan Hal Tersebut

"dak taulah aku, meraso dak diangeep be kadang" (P1)

"padahal keluargo tapi cak dak peduli" (P2)

"aku meraso mereka dak peduli" (P3)

"dak sayang” (P4)

“mak aku tani, kalo keluargo laki dak peduli samo aku” (P5)

"dak peduli caknyo" (P6)

"ntah lah yo, cak dak tau be" (P7)

\section{Tema 9. Bagaimana Reaksi Anda dalam Menghadapi Perlakuan Tersebut}

Reaksi dalam menghadapi perlakuan berdasarkan informasi dari partisipan yaitu:

"sedih" (P1)

"sedih" (P2)

"sedih" (P3)

"sedih" (P4)

"nangis" (P5)

"nangis" (P6)

"sedih ajo" (P7)

\section{Tema 10. Pola Apa yang Ibu Terapkan dalam Proses Menghadapi Persalinan di} Masa Pandemi COVID-19

Pola yang diterapkan berdasarkan informasi dari partisipan yaitu:

"sering cuci tangan, kalau keluargo keluar pake masker" (P1)

“cuci tangan, pakai masker, terus jago jarak kek orang lain” (P2)

"sering-sering cuci tangan kalau endak megang bayi, makan yang bergizi” (P3)

"cuci tangan, jago jarak orang lain kek bayi" (P4)

"cuci tangan, keluargo kalau keluar pas ado yang penting ajo" (P5)

“cuci tangan, pakai masker" (P6)

“cuci tangan, pakai masker jago jarak kak” (P7)

Tema 11. Dukungan Akses Pelayanan Kesehatan yang Diperoleh Ibu Muda dalam Perawatan Bayi Saat Sakit di Masa Pandemi Ini

Dukungan yang diperoleh berdasarkan informasi dari partisipan yaitu:

"pas anak demam cemee nak ke puskes ngeriii, dem berobat kampong tulah" (P1) "ado badanyo pane, nak ke RS cemee gek kato orang covid kan, bawa dukun tulah" (P2)

"pas bayi mencret seharian, RS dan Puskes ngebatasi kunjungan, rawat dewek ngeri e kalo ke $R S$ ” (P3)

"akunyo cemee kalo dibawa ke sano, gek disangko covid bayi ku” (P4)

"pas perutnyo kembung dak brenti betangisan, laki dak boleh bawa ke puskes, gek covid katonyo" (P5)

"berobat kek dukun dekek rumah tulah, dak brani aku ke puskes gek keno covid pulo" (P6)

"berobat kampong bae, aku dan laki cemee kalo ke puskes/RS. Gek kato orang covid pulo kami” (P7) 


\section{PEMBAHASAN}

\section{Tema 1. Usia dan Pendidikan Terakhir Ibu}

Hasil penelitian ini menunjukkan usia ibu remaja berada pada tahap remaja akhir. Sesuai dengan hasil penelitian ini ibu usia remaja terdapat berbagai usia seperti partisipan 1,5 dan 7 melahirkan pada usia 19 tahun dan partisipan 3,4 dan 6 melahirkan pada usia 21 tahun dan partisian 2 melahirkan usia 20 tahun. Hasil penelitian yang dilakukan oleh Zakiah (2020) menunjukkan bahwa sebanyak 121 (87,7\%) remaja putri hamil pada usia remaja 16-19 tahun dengan penyebab kehamilan yaitu seks bebas sebanyak $137(93,3 \%)$ dan saat hamil sebagian besar remaja putri yang mengalami kehamilan usia remaja melakukan kontak dengan tenaga kesehatan pada trimester II sebanyak $78(56,5 \%)$.

Sesuai dengan hasil penelitian ini, ibu usia remaja didapati tingkat pendidikan terakhir yaitu SMP dan SMA yang terdiri dari partisipan 1, 5 dan 7 pendidikan terakhirnya SMP, sedangkan partisipan 2,3 4 dan 6 pendidikan terakhirnya SMA. Berdasarkan hasil penelitian yang dilakukan oleh Silvani (2020) didapatkan bahwa pendidikan terakhir ibu usia remaja sebanyak 47 (49\%) memiliki pendidikan dasar SD dan SMP.

\section{Tema 2. Pengertian Persalinan}

Hasil penelitian ini menunjukkan bahwa ibu usia remaja hanya mampu menjawab pengertian persalinan yaitu proses mengeluarkan bayi saja. Padahal secara teori persalinan adalah proses pengeluaran janin yang terjadi pada kehamilan cukup bulan (37 sampai 42 minggu), lahir spontan dengan presentasi belakang kepala yang berlangsung dalam 18 jam tanpa komplikasi baik pada ibu maupun pada janin.

Proses persalinan yang aman di era COVID-19 ialah tetap bersalin di fasilitas pelayanan kesehatan. Segera ke fasilitas kesehatan jika sudah ada tanda-tanda persalinan. Rujukan terencana untuk ibu hamil dengan PDP atau konfirmasi COVID-19, dilakukan evaluasi urgency-nya dan apabila memungkinkan untuk ditunda untuk mengurangi risiko penularan sampai infeksi terkonfirmasi atau keadaan akut sudah teratasi. Apabila operasi tidak dapat ditunda maka operasi sesuai prosedur standar dengan pencegaham infeksi sesuai standar APD level 3 (Utami \& Yuliasari, 2020).

\section{Tema 3. Tahap Persalinan}

Hasil penelitian ini menunjukkan bahwa ibu usia remaja hanya mampu menjawab terkait proses persalinan sampai dengan kala 3 saja, padahal proses persalinan meliputi 4 kala, di mana kala I adalah waktu pembukaan serviks $1-10 \mathrm{~cm}$. kala II adalah waktu dikeluarkan janin. Kala III merupakan kala dilepaskan dan dikeluarkannya ari. Adapun kala IV digunakan untuk observasi post partum pada 2 jam pertama.

Nyeri saat persalinan merupakan kondisi fisiologis yang secara umum dialami oleh hampir semua ibu bersalin. Nyeri persalinan merupakan sebuah pengalaman subjektif disebabkan oleh iskemik otot uteri, penarikan traksi ligament uteri, traksi ovarium, tuba fallopi, distensi bagian bahwa uteri, otot dasar panggul dan perineum. Pada persalinan kala 1 pembukaan 4-8 cm (Magfirah \& Idwar, 2020).

Kala II adalah proses persalinan berlangsung, proses persalinan yang dilakukan dengan massage perineum mendapatkan hasil partisipan pertama proses percepatan persalinan berlangsung dalam waktu 15 menit. Pada partisipan kedua berlangsung dalam waktu 10 menit dan pada partisipan ketiga proses percepatan persalinan berlangsung dalam waktu 20 menit (Laspiriyanti \& Puspitasari, 2020). Adapun kala III 
merupakan proses dilepaskan dan dikeluarkannya ari. Pada tahap ini yang harus dilakukan yaitu manajemen aktif kala III dan melakukan pemantauan perdarahan dan hal yang dilakukan pada kala IV observasi postpartum (Hilinti et al., 2020).

\section{Tema 4. Perasaan Ibu Ketika Proses Melahirkan}

Hasil penelitian ini menunjukkan bahwa ibu usia remaja mengalami kecemasan dan mengalami stress ketika proses melahirkan di masa pandemi COVID-19 dan memberikan kualitas yang buruk terhadap perawatan selama masa pandemi. Didukung oleh penelitian Yuliani \& Aini (2020) 87\% ibu melahirkan mengalami kecemasan terkait pandemi COVID-19 tersebut. Studi lain melaporkan bahwa kekhawatiran ibu tentang resiko terpapar COVID-19, masa karantina dan langkah-langkah yang diadopsi selama pandemi COVID-19 dapat berdampak pada pemikiran dan emosi ibu baru (Zanardo et al., 2020).

\section{Tema 5. Lama Ibu Merasa Cemas/Stress}

Penelitian ini memperlihatkan bahwa partisipan 1, 4, 6 dan 7 mengalami kecemasan selama 3 bulan, partisipan 2 dan 5 mengalami kecemasan selama 3,5 bulan dan partisipan 3 mengalami kecemasan selama 4 bulan. Dari data diatas didapatkan bahwa proses cemas pada ibu usia remaja yang melahirkan anak di masa pandemi berlangsung selama 3-4 bulan. Didukung oleh hasil penelitian yang dilakukan oleh Yuliani \& Aini (2020) didapatkan bahwa 87\% ibu nifas mengalami kecemasan kategori ringan-sedang, hasil penelitian tersebut selaras dengan hasil penelitian ini, menggambarkan bahwa mayoritas ibu nifas mengalami kecemasan tingkat sedang selama melahirkan di masa pandemi COVID-19.

\section{Tema 6. Tindakan yang Dilakukan Ketika Perasaan Cemas/Stress/Khawatir Muncul}

Secara umum, kecemasan pada ibu hamil dan ibu nifas dapat berdampak pada kesehatan ibu dan janin atau bayi. Dengan adanya pandemi COVID-19 dapat meningkatkan insiden atau tingkatan kecemasan pada ibu hamil dan ibu nifas, sehingga permasalahn tersebut memerlukan penanganan lebih lanjut, untuk mengurangi dampak negatif pada kesejahteraan ibu dan janin atau bayi (Yuliani \& Aini, 2020).

Hasil penelitian ini didapatkan partisipan 1, 2, 3 dan 5 ketika cemas berdoa untuk mengurangi kecemasannya sedangkan pastisipan 4, 6 dan 7 melakukan teknik tarik nafas untuk mengurangi kecemasannya. Hasil penelitian yang dilakukan oleh Kuswaningsih (2020) didapatka hasil bahwa sesudah melakukan teknik relaksasi nafas dalam terjadi penurunan kecemasan menjadi 11,22 dari yang awal skor rata-rata tingkat kecemasannya 15,89 .

\section{Tema 7. Perlakuan Keluarga Ketika Perawatan BBL di Rumah}

Berdasarkan hasil penelitian ini, didapatkan bahwa keluarga memberikan dukungan serta memberi saran pada ibu muda dalam merawat bayinya di masa pandemi, namun keluarga tidak bisa sepenuhnya membantu ibu muda ketika melakukan perawatan BBL dikarenakan keluarga juga sibuk dengan pekerjaanya. Didukung oleh penelitian yang dilakukan oleh Wahyuni et al., (2020) didaptkan hasil bahwa peran serta keluarga dalam PHBS meningkat 16 orang (80\%), teknik perawatan ibu da bayi baik 13 orang (65\%). Diharapkan agar ibu nifas dan keluarga tetap melaksanakan PHBS, perawatan ibu dan bayi serta upaya pencegahan COVID-19 selama masa pandemi ini. 


\section{Tema 8. Tanggapan Mengenai Sikap Keluarga}

Hasil menunjukkan bahwa partisipan merasa kurangnya dukungan dari keluarga serta merasa keluarga tidak peduli terhadap kondisi yang sedang dirasakan oleh partisipan. Berdasarkan penelitian yang dilakukan oleh Pertiwi (2020) disimpulkan bahwa dukungan keluarga sangat penting bagi ibu postpartum, semakin tinggi dukungan keluarga dan self efficacy semakin rendah peluang terjadinya depresi postpartum. Ibu postpartum yang mendapatkan dukungan keluarga tinggi akan merasa diperhatikan, disayang dan dapat berbagi beban sehingga mampu mengurangi stress yang pada akhirnya mengurangi terjadinya depresi postpartum.

\section{Tema 9. Reaksi dalam Menghadapi Perlakuan Tersebut}

Penelitian ini memperoleh hasil bahwa partisipan merasa sedih dan tidak segan untuk mengangis atas perlakuan yang di berikan oleh kelurganya. partisipan 1, 2, 3, 4 dan 7 merasa sedih atas perlakuan yang diberikan keluargnya tersebut, partisipan 5 dan 6 menangis atas perlakuan keluargnya. Berdasarkan penelitian yang dilakukan oleh Ajeng \& Oktaviansyah (2020) menunjukkan bahwa dengan semakin tinggi tingkat kemampuan ibu dalam menstrategikan bagaimana menyesuaikan intensitas atau durasi dan reaksi emosional ke tahap yang lebih menyenangkan untuk mencapai tujuan maka akan semakin menurunkan tingkat kecemasan. Strategi ini adalah suatu bentuk perubahan kognitif dalam menguraikan suatu situasi yang secara potensial mendatangkan emosi sehingga bisa mengubah respon emosional.

\section{Tema 10. Pola Apa yang Diterapkan dalam Proses Menghadapi Persalinan di Masa Pandami COVID-19}

Untuk meningkatkan kewaspadaan pada ibu dan bayi pasca bersalin menjaga diri agar tidak tertular dengan wabh COVID-19 dengan protokol kesehatan yang sudah ditetapkan seperti ibu menyusui dan pengasuh memahami penggunaan masker yang benar dan etika batuk, menjaga kebersihan diri dan lingkungan rumah dan ketika berkunjung ke fasyankes, serta menyampaikan status orang dalam pemantauan (ODP) pasien dalam pengawasan (PDP) atau terkonfirmasi positif COVID-19 jika ada di lingkungan sekitar kita. Selain itu, diperlukan tindakan preventif agar selalu sehat dan dapat merawat diri dan bayi dengan penerapan PHBS yang tepat agar mencegah kejadian infeksi pada masa nifas.

\section{Tema 11. Dukungan Akses Pelayanan Kesehatan yang Diperoleh Ibu Muda dalam Perawatan Bayi Saat Sakit di Masa Pandemi Ini}

Hasil penelitian ini memperlihatkan bahwa dukungan akses pelayanan kesehatan yang diperoleh ibu muda dalam perawatan bayi saat sakit di masa pandemi ini menerima perlakuan dengan kualitas akses pelayanan kesehatan yang kurang. Keluarga lebih memilih untuk berobat di kampung mereka dikarenakan perasaan cemas dan takut jika anaknya tertular COVID-19 ketika dibawa ke pelayanan kesehatan seperti puskesmas dan RS.

Berdasarkan penelitian yang dilakukan oleh Mollard \& Wittmaack (2021) mendapatkan hasil bahwa $61 \%$ wanita melaporkan dukungan yang tidak memadai untuk persalinan selama masa pandemi COVID-19 dan 20,5\% melaporkan bahwa mereka tidak merasa aman melahirkan di rumah sakit. Perempuan yang dites positif COVID-19 lebih cenderung berasal dari ras Asia, mereka melakukan persalinan secara caesar, ketika melahirkan tidak didampingi oleh pasangan dan menghentikan menyusui 
sebelum 6 minggu. Perubahan terkait pandemi pada praktik keperawatan maternitas mungkin terjadi dan mempengaruhi persepsi wanita melahirkan tentang keamanan dan dukungan di lingkungan rumah sakit dan gejala stres yang muncul selama masa pandemi COVID-19.

\section{SIMPULAN}

Ibu usia remaja yang melahirkan selama pandemi COVID-19 menderita cemas tingkat sedang dan minim dukungan keluarga saat melahirkan serta menerima perlakuan dengan kualitas akses pelayanan kesehatan yang kurang.

\section{SARAN}

\section{Bagi Keluarga}

Diharapkan selalu mendampingi ibu usia remaja dan memantau tindakan yang ibu lakukan terhadap bayinya. Selain itu memberikan kasih sayang, dukungan, perlindungan dan perhatian pada ibu usia remaja. Untuk ibu usia remaja lebih meningkatkan pengetahuan bagaimana cara perawatan bayi baru lahir selama masa pandemi COVID19.

\section{Fasilitas Pelayanan Kesehatan}

Perlu adanya penyelenggaraan webinar yang dilaksanakan oleh perawat komunitas sehingga mampu membantu memberikan pemahaman kepada masyarakat tentang pentingnya beradaptasi di masa pandemi, serta pemahaman kepada ibu di masa nifas dengan adaptasi kebiasaan baru dan perawatan anak ketika sakit di masa pandemi COVID-19.

\section{DAFTAR PUSTAKA}

Ajeng, T. S., \& Oktaviansyah, A. D. (2020). Hubungan Regulasi Emosi dengan Kecemasan pada Ibu Hamil [Universitas Muhammadiyah Surakarta]. http://eprints.ums.ac.id/88128/

Hilinti, Y., Budi, P., \& Ahmad, M. (2020). Modul Asuhan Persalinan Kala III dengan Metode Preceptorship terhadap Keterampilan Mahasiswa DIII Kebidanan. Jurnal Keperawatan Silampari, 3(2), 477-488. https://doi.org/10.31539/jks.v3i2.1036

Laspiriyanti, I., \& Puspitasari, L. (2020). Efektifitas Massage Perineum untuk Percepatan Persalinan Kala II pada Ibu Bersalin. Jurnal Kebidanan Harapan Ibu Pekalongan, 7(1), 21-26. https://doi.org/10.37402/jurbidhip.vol7.iss1.69

Magfirah, M., \& Idwar, I. (2020). Metode Massage Effluerage terhadap Intensitas Nyeri pada Persalinan Kala I. Jurnal Kebidanan Malahayati, 6(4), 481-481. https://doi.org/10.33024/jkm.v6i4.3009

Mollard, E., \& Wittmaack, A. (2021). Experiences of Women who Gave Birth in US Hospitals During the COVID-19 Pandemic. Journal of Patient Experience, 8, 1-6. https://doi.org/10.1177/2374373520981492

Mortazavi, F., \& Ghardashi, F. (2021). The Lived Experiences of Pragnant Women During Covid-19 Pandemic: A Descriptive Phenomenological Study. BMC Pregnancy Childbirth, 21(193), 1-18. https://doi.org/https://doi.org/10.1186/s12884-021-03691-y

Nosratabadi, M., Sarabi, N., \& Masoudiyekta, L. (2020). A Case Report of Vaginal Delivery at Home Due to Fear of Covid-19. Iranian Journal of Psychiatry, 15(4), 366-369. https://doi.org/10.18502/ijps.v15i4.4306 
Pertiwi, C. E. (2020). Hubungan Dukungan Keluarga dan Self Efficacy dengan Kejadian Depresi Postpartum [Universitas Airlangga]. http://repository.unair.ac.id/101911/

Silvani, B. T. (2020). Faktor-Faktor Yang Mempengaruhi Terjadinya Kehamilan Usia Remaja di PMB Wilayah Kerja Puskesmas Pujokerto Lampung Tengah. Jurnal Keperawatan, 1(1), 69-70. http://repository.poltekkes-tjk.ac.id/1295/

Utami, V. W., \& Yuliasari, D. (2020). Sosialiasasi Proses Persalinan yang Aman di Era Pandemi Covid-19. Jurnal Perak Malahayati, 2(2), 95-108. http://www.ejurnalmalahayati.ac.id/index.php/PERAKMALAHAYATI/article/vie w/3453

Wahyuni, I., Hasanah, U., Yanti, N., \& Putra, I. D. (2020). Pemberdayaan Ibu Pasca Bersalin, Keluarga, tentang PHBS, Perawatan Ibu dan Bayi serta Pencegahan Penularan COVID-19. Jurnal ABDIMAS-HIP, 1(2), 78-87. http://akbidhipekalongan.ac.id/e-journal/index.php/abdimaship/article/view/105

Yuliani, D. R., \& Aini, F. N. (2020). Kecemasan Ibu Hamil dan Nifas pada Masa Pandemi COVID-19 di Kecamatan Baturraden. Jurnal Sains Kebidanan, 2(2), 1114. https://doi.org/10.31983/jsk.v2i2.6487

Zakiah, U. (2020). Gambaran Kehamilan Remaja Ditinjau dari Umur, Penyebab Kehamilan dan Kontak Pertama dengan Tenaga Kesehatan di Wilayah Kerja Puskesmas Sikumana Kota Kupang. CHMK Midwifery Scientific Journal, 3, 128133. http://cyber-chmk.net/ojs/index.php/bidan/article/view/767

Zanardo, V., Manghina, V., Giliberti, L., Vettore, M., Severino, L., \& Straface, G. (2020). Psychological Impact of COVID-19 Quarantine Measures in Northeastern Italy on Mothers in the Immediate Postpartum Period. International Journal of Gynecology and Obstetrics, 150(2), 184-188. https://doi.org/10.1002/ijgo.13249 